\title{
Microscopical Evaluation, Phytochemical Analysis and HPTLC Fingerprinting of Tuber of Actinoscirpus grossus (L.f.) Goetgh. \& D.A.Simpson
}

\author{
Savin Chanthala Ganapathi ${ }^{1}$, Rajendra Holla ${ }^{2}$, Shivaraja Shankara ${ }^{3}$, Sunil Kumar Koppala Narayana ${ }^{4 *}$, Ravi Mun- \\ dugaru $^{5}$
}

\section{Savin Chanthala Ga- napathi ${ }^{1}$, Rajendra Holla ${ }^{2}$, Shivaraja Shankara3, Sunil Kumar Koppala Naraya- na $^{4 *}$, Ravi Mundugaru ${ }^{5}$ \\ 'Department of Pharmacology, KVG Medical College and Hospital, Sullia, Dakshina Kannada, Karnataka, 574327. INDIA. \\ 2Department of Pharmacology, KS Hegde Medical Academy, NITTE University, Deralakatte, Mangalore, Karnataka, 575018. INDIA. \\ ${ }^{3}$ Department of Biochemistry, KVG Med- ical College \& Hospital, Sullia, Dakshina Kannada, Karnataka, 574327. INDIA. \\ ${ }^{4}$ Research Officer, Department of Pharmacognosy, Siddha Central Research Institute, Central Council for Research in Siddha, Arumbakkam, Chennai, 600106. INDIA. \\ ${ }^{5}$ SDM Centre for Research in Ayurveda and Allied Sciences, Laxminarayana Nagar, Kuthpady, Udupi, Karnataka, 574118. INDIA. \\ Correspondence:}

Dr. Sunil Kumar Koppala Narayana Research Officer, Department of Pharmacognosy, Siddha Central Research Institute, Central Council for Research in Siddha, Arumbakkam, Chennai, INDIA.

Phone no :+917406111071

E-mail: sunilkumarnarayanan@gmail.com

History

- Submission Date: 07-05-2017;

- Review completed: 27-05-2017;

- Accepted Date: 18-06-2017

DOI : 10.5530/pj.2017.5.104

Article Available online

http://www.phcogj.com/v9/i5

Copyright

(C) 2017 Phcog.Net. This is an openaccess article distributed under the terms of the Creative Commons Attribution 4.0 International license.

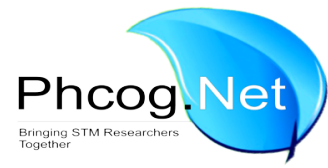

\begin{abstract}
Actinoscirpus grossus (L.f.) Goetgh. \& D.A.Simpson (Cyperaceae), is a Perennial with long stolons and rhizomes ending in small tubers. It is popularly known as Kasheruk in Sanskrit. The plant is traditionally used as anti-diarrheal, anti-emetic, and tonic to the liver. In order to do the detail standardization of plant macro-microscopical observation, phytochemical analysis and HPTLC Finger printing of tuber was performed according to pharmacopoeia procedure. Microscopic analysis has showed thick-walled polygonal epidermal cells of young root stalk in surface view, elongated phloem parenchyma filled with starch grains, spiral to annular vessel fragments and simple starch grains scattered all over the powder. Phytochemical analysis showed presence of carbohydrate, coumarins, flavanoids, steroid, tannin, and terpenoid. Ethanol extract of plant were fingerprinted in toluene: ethyl acetate (7:3). The developed plates were visualized in UV 254, 366, and then derivatised with vanillin sulphuric acid and scanned under UV 254 and $366 \mathrm{~nm}$. These specific identities will be useful in identification and authentication of the raw drug.
\end{abstract}

Key words: Ethanol extract, HPTLC, Pharmacognosy, Phytochemical analysis, Quality control, Standardization

\section{INTRODUCTION}

The plant Actinoscirpus grossus (L.f.) Goetgh. \& D.A.Simpson of Cyperaceae family is popularly known as Kasheruk mentioned in dravyaguna. ${ }^{1}$ A. grossus is one of traditional herbs which claims to be having many useful properties anti diarrheal, anti-emetic, non-specific anti spasmodic, progesterone like activity, and used in digestive disorders. The root is slightly sweet, cooling, laxative, tonic to the liver, diuretic, useful in burning sensations, vomiting, diarrhea ${ }^{2,3}$ and has astringent property. ${ }^{4}$ The tuber of $A$. grossus was also used traditionally as hepatoprotective agent. A. grossus is principal weed of four South East Asian Countries occuring in swampy and inundated places, pools, ditches and marshses. ${ }^{5}$ There are many families of phytochemicals helping a human body in a variety of ways. Traditional folk remedies from plants have always guided scientists to search for new medicationsin ordertomaintainhealthylife forhumans. ${ }^{6}$ Before starting any trial on a drug it has to undergo detailed standardization, chemical analysis and pharmacological property evaluation. Pharmacognostical study is the initial step to confirm the identity and to assess the quality and purity of crude drug. ${ }^{7}$ Due to many reasons such as similar morphological features, presences of similar active principles etc, medicinal plant materials were being adulterated. Therapeutic activity

of herbal products is affected badly by practice of substitution and adulteration, therefore systematic identification of drugs and their substitutes is an essential step while producing standardized herbal products. Standardization of herbal drug is not an easy task as numerous factors influence the bio efficacy and reproducible therapeutic effect in order to obtain quality oriented herbal products. ${ }^{8}$ In the present study standardization of tuber extract $A$. grossus was performed. Preliminary phytochemical study, powder microscopy and HPTLC of tuber extract of plant are documented.

\section{MATERIALS AND METHODS}

Plant materials

The authenticated sample of plant tuber powder of A. grossus was purchased from Vaidya Hukam Chand Arogyadham Gharaunda, Haryana India. The voucher specimen (No. 495/14101822) was deposited at the Pharmacognosy Laboratory of S.D.M Centre for Research in Ayurveda and Allied Sciences, Udupi for future reference. For powder microscopy, the sample was sift through mesh 60 ; the powder was stored in glass vial for the phytochemical examination and HPTLC study.

Cite this article : Savin GC, Holla R, Shankara S, Sunil Kumar KN, Ravi M. Title-Microscopical Evaluation, Phytochemical Analysis and HPTLC Fingerprinting of Tuber of Actinoscirpus grossus (L.f.)Goetgh. \& D.A.Simpson. Pharmacog J. 2017;9(5):657-62. 


\section{Powder microscopy}

A pinch of powder was warmed with drops of chloral hydrate on a microscopic slide and mounted in glycerin. Slides observed under microscope and diagnostic characters were observed and photographed using Zeiss AXIO trinocular microscope attached with Zeiss AxioCam camera under bright field light. Magnifications of the figures are indicated by the scale-bars. ${ }^{9}$

\section{Preliminary phytochemical analysis}

Preliminary phytochemical investigation was done with the coarse powder to detect the presence of carbohydrate, coumarins, flavonoids, steroid, tannin, and terpenoid in ethanolic extract. ${ }^{10}$

HPTLC

$1 \mathrm{~g}$ of powder was extracted with $10 \mathrm{ml}$ of ethanol, 4,8 and $12 \mu \mathrm{l}$ of the above extract was applied on a pre-coated silica gel F254 on aluminum plates to a band width of $7 \mathrm{~mm}$ using Linomat 5 TLC applicator. The plate was developed in Toluene: Ethyl acetate (7:3). The developed plates were visualized in UV 254, 366, and then derivatised with vanillin sulphuric acid and scanned under UV 254 and $366 \mathrm{~nm}$ and colour of the spots and densitometric scan were recorded. ${ }^{11-14}$

\section{RESULTS}

Powder microscopy study of tuber powder of A. grossus showed characters such as thick-walled polygonal epidermal cells of young root stalk in surface view, cells of cork in few rows in surface view, longitudinally cut cork cells in few layers, parenchyma as such or attached with thin-walled simple and pitted fibres, thick and thin walled parenchyma with or without yellowish brown contents, elongated phloem parenchyma filled with starch grains, spiral to annular vessel fragments and simple starch grains scattered all over the powder [Figure 1].

HPTLC photo documentation of alcoholic extract of A. grossus showed 7, 13 and 14 spots with characteristics $\mathrm{R}_{\mathrm{f}}$ value and colors under short $\mathrm{UV}$, long UV and white light after derivatisation respectively [Table 1]. Spots with $\mathrm{R}_{\mathrm{f}}$ value $0.27,0.36$ and 0.81 were detected in all three-detection method though in different colors. HPTLC densitometric scan at $254 \mathrm{~nm}$ showed maximum number of detectable spots counting to 11 with different percentage area. HPTLC with photo documentation and densitometric scan can be used as finger print of chemical component present in ethanol extract of $A$. grossus [Figure 2,3].

Powdered tuber extract of plant A. grossus showed presence of carbohydrate, coumarins, flavonoids, steroid, tannin, and terpenoid [Table 2].

\section{DISCUSSION}

The plant A. grossus is a principal weed of four South East Asian countries. It is well known herb which is used in Indian System of medicine. Medicinal plant materials are being adulterated due to many reasons. The practice of substitution and adulteration will badly affect the therapeutic activity of herbal products. Microscopical analysis of plants is invaluable for assuring the identity of the material and as initial screening test for impurities. ${ }^{15}$ Authentication and quality assessment of herbal materials deals with the pharmacognosy that is based on macroscopic and microscopic features. A big quantum of research works in the area of authentication of the correct plant source has been undertaken to provide means

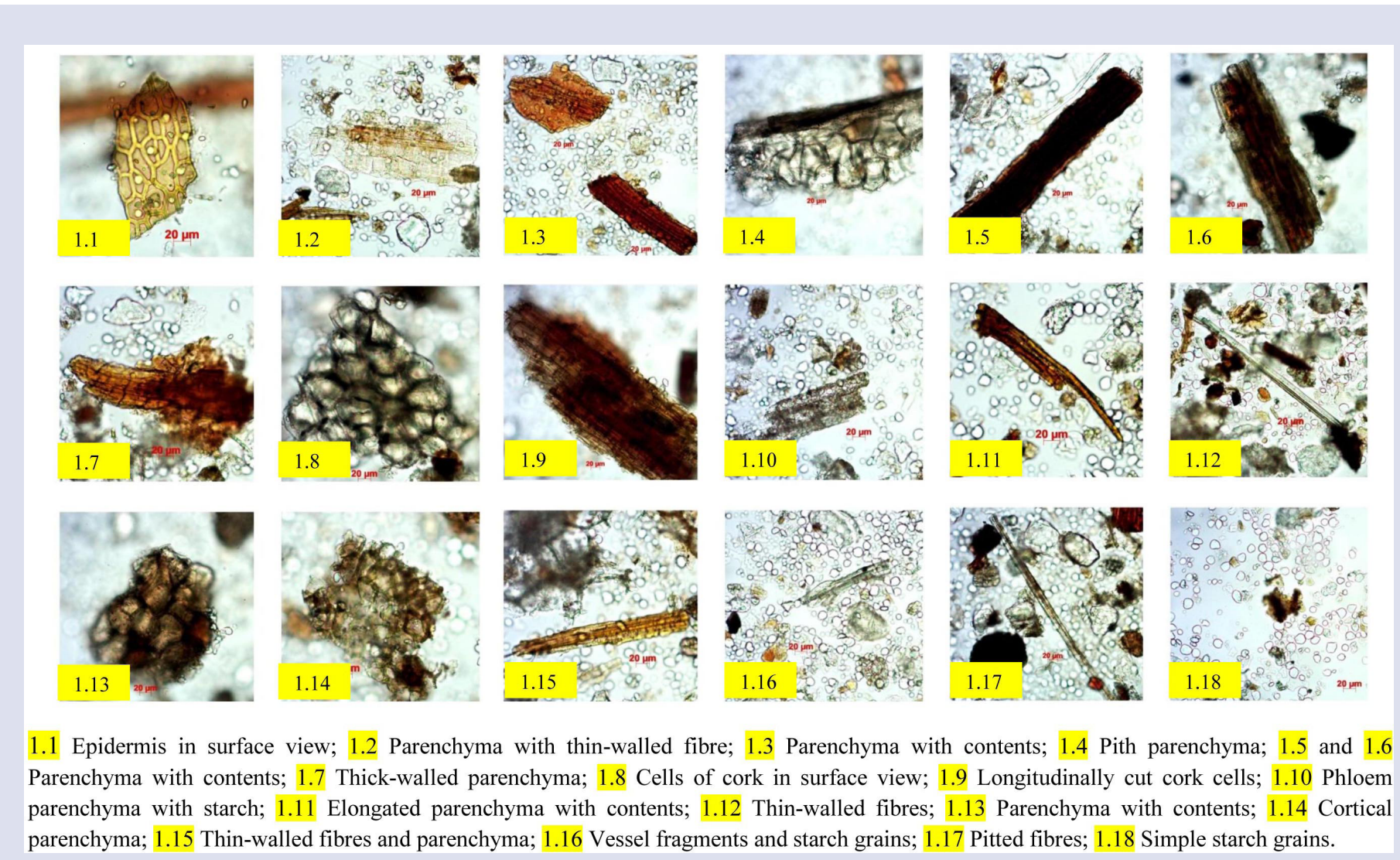

Figure 1: Powder microscopy of tuber of Actinoscirpus grossus (L.f.) Goetgh.\&D.A.Simpson 
Table 1: $\mathbf{R}_{\mathrm{f}}$ values of ethanol extract of tuber of Actinoscirpus grossus (L.f.) Goetgh. and D.A. Simpson at 254 $\mathrm{nm}(12 \mu \mathrm{l})$

\begin{tabular}{|c|c|c|}
\hline Under short UV & Under long UV & Under white light after derivatisation \\
\hline- & 0.03(F L Violet) & - \\
\hline- & 0.06(F L Violet) & 0.06 (Violet) \\
\hline- & 0.09(F L Violet) & - \\
\hline- & - & 0.12 (Violet) \\
\hline- & 0.14 (F L Violet) & - \\
\hline $0.16(\mathrm{~L}$ Green $)$ & - & - \\
\hline- & 0.18 (F L Violet) & - \\
\hline- & - & 0.21 (L Violet) \\
\hline 0.27 (L Green) & 0.27 (F L Violet) & 0.27 (L Violet) \\
\hline- & - & 0.32 (L Violet) \\
\hline 0.36(L Green) & 0.36(F L Violet) & 0.36(L Violet) \\
\hline- & - & 0.38 (L Violet) \\
\hline- & 0.40(F L Violet) & - \\
\hline- & 0.44 (F L Violet) & 0.44(Violet) \\
\hline 0.46(L Green) & - & 0.46 (L Violet) \\
\hline- & - & 0.52 (L Violet) \\
\hline- & 0.54 (F L Violet) & - \\
\hline 0.56(L Green) & - & - \\
\hline- & 0.60(F L Violet) & 0.60 (L Violet) \\
\hline- & - & 0.67(L Violet) \\
\hline 0.81(L Green) & 0.81 (F Violet) & 0.81 (L Violet) \\
\hline 0.86(Green) & - & - \\
\hline- & - & 0.92 (L Violet) \\
\hline- & 0.95 (F L Violet) & - \\
\hline
\end{tabular}

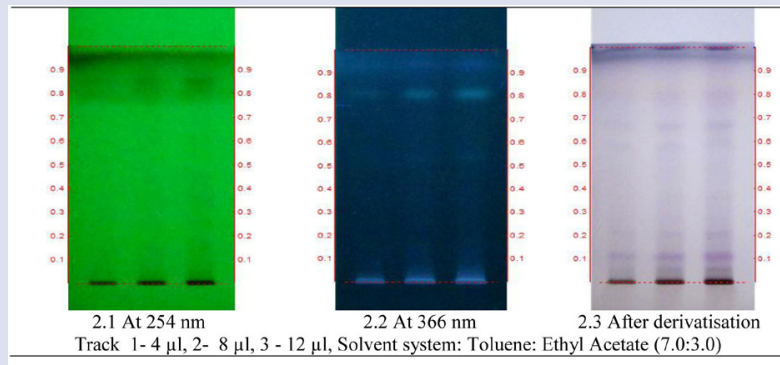

Figure 3. Densitometric scan of the ethanolic extract of Actinoscirpus grossus (L.f.) Goetgh. \& D.A.Simpson (At $12 \mu \mathrm{l})$

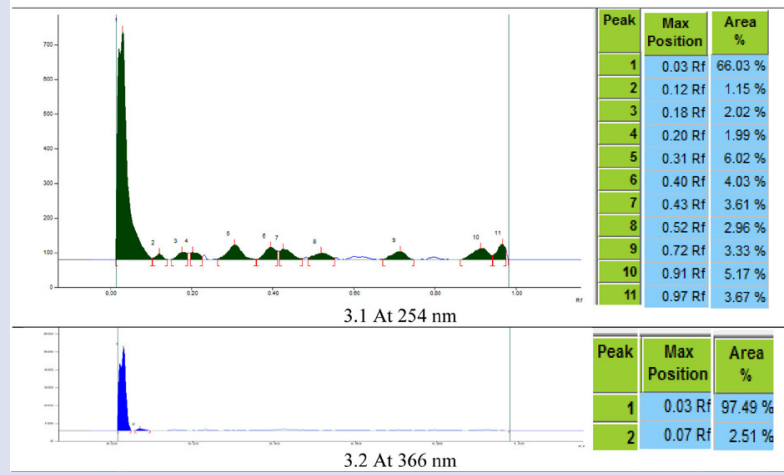

Figure 2: Photo documentation of ethanolic extract of Actinoscirpus grossus (L.f.) Goetgh.\&D.A. Simpson

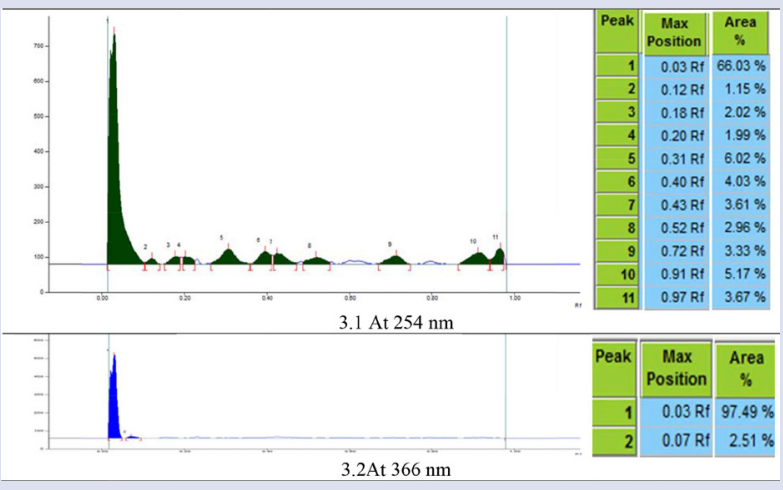

Figure 3: Densitometric scan of the ethanolic extract of tuber of Actinoscirpus grossus (L.f.) Goetgh.\&D.A. Simpson (12 $\mu \mathrm{l})$.

of differentiation among many available plant sources. ${ }^{16-18}$ Sophisticated modern research tools for evaluation of the plant drugs are available but microscopic method is still one of the simplest and cheapest methods to establish the correct identity of the source of material. ${ }^{19}$ According to the world health organization (WHO) the macroscopic and microscopic description of a plant is the first step to establish the identity before any tests are undertaken.

Preliminary phytochemical analysis showed presence of carbohydrate, coumarins, flavonoids, steroid, tannin, and terpenoid which may help in the hepatoprotective activity of plant. 
Table 2: Preliminary phytochemical analysis ethanol extract of tuber of Actinoscirpus grossus (L.f.) Goetgh. D.A.Simpson

\begin{tabular}{|c|c|c|c|}
\hline Tests & Colour if positive & Acotinoscirpus grossus & Results \\
\hline \multicolumn{4}{|l|}{ Alkaloids } \\
\hline Dragendrof's test & Orange precipitate & Brown Colour Solution & \\
\hline Wagners test & Red precipitate & Brown Colour Solution & Absent \\
\hline Mayers test & Dull white precipitate & Light yellow Colour & \\
\hline Hagers test & Yellow precipitate & Light yellow Colour & \\
\hline \multicolumn{4}{|l|}{ Steroids } \\
\hline Liebermann- buchard test & Bluish green & Green colour & Present \\
\hline Salkowski test & Bluish red to cherry red & Red colour at junction & \\
\hline \multicolumn{4}{|l|}{ Carbohydrate } \\
\hline Molish test & Violet ring & Violet ring & \\
\hline Fehlings test & Brick red precipitate & Brick red precipitate & Present \\
\hline Benedicts test & Red precipitate & Red precipitate & \\
\hline \multicolumn{4}{|l|}{ Tannin } \\
\hline With $\mathrm{FeCl}_{3}$ & Dark blue or green or brown & Dark Green colour. & Present \\
\hline \multicolumn{4}{|l|}{ Flavanoids } \\
\hline Shinoda's test & Red to pink & Pink Colour & Present \\
\hline \multicolumn{4}{|l|}{ Saponins } \\
\hline $\begin{array}{l}\text { With } \mathrm{NaHCO}_{3} \\
\text { Triterpenoids }\end{array}$ & Stable froth & No froth & Absent \\
\hline \multicolumn{4}{|l|}{ Coumarins } \\
\hline With $2 \mathrm{~N} \mathrm{NaOH}$ & Yellow & Yellow Colour Solution & Present \\
\hline \multicolumn{4}{|l|}{ Phenols } \\
\hline \multicolumn{4}{|l|}{ Carboxylic acid } \\
\hline $\begin{array}{l}\text { With water and } \mathrm{NaHCO}_{3} \\
\text { Resin }\end{array}$ & Brisk effervescence & No brisk effervescence & Absent \\
\hline With aqueous acetone & Turbidity & No Turbidity & Absent \\
\hline \multicolumn{4}{|l|}{ Quinone } \\
\hline $5 \% \mathrm{NaOH}$ & Pink/purple/red & Dark Green Colour & Absent \\
\hline
\end{tabular}

HPTLC is one of the sophisticated instrumental techniques for qualitative and quantitative analysis of the herbs and herbal drugs. HPTLC serves as quality assessment tool which helps in identification of variation in chemical composition in plants. HPTLC fingerprinting shows different $\mathrm{R}_{\mathrm{f}}$ values can be used as quality indicating finger printing for A. grossus in the dried form. High-performance thin-layer chromatography (HPTLC) is a form of thin-layer chromatography (TLC) that provides superior separation using optimized coating material, novel procedures for mobile-phase feeding, layer conditioning, and improved sample application. It promotes for higher separation efficiencies, shorter analysis time, lower amounts of mobile phase, and efficient data acquisition and processing. ${ }^{20}$ Among the modern analytical tools HPTLC is a powerful analytical method equally suitable for qualitative analytical tasks HPTLC produces visible chromatogram complex information about the entire sample and multiple samples are seen simultaneously, so that reference and test samples can be compared for identification. The analysis and quality control of herbal medicines are moving a step ahead towards an integrative and comprehensive direction, to tackle the complex nature of herbal medicines. High-performance thin layer chromatography
(HPTLC) is one of the sophisticated instrumental techniques for qualitative and quantitative analysis of the herbs and herbal drugs. ${ }^{21,22}$ Marker compound means chemical constituents within a medicinal plant that can be used to verify its potency or identity. For sometimes, the marker compounds may be described as active ingredients or chemicals that confirm the correct botanical identity of the starting material. It is very difficult to identify correct marker compounds for all traditional medicines, because some medicines have unknown active constituents and others have multiple active constituents. By using chromatographic fingerprints, the authentication and identification of herbal medicines can be accurately conducted even if the amount and/or concentration of the chemically characteristic constituents is not the same for different samples of drug. ${ }^{23-25}$

One of the drawbacks of herbal medicine is lack of standardization and quality control profiles of correct identification of species. The mistaken substitution and misclassification of species is real danger in preparation and administration of herbal medicine. The features available in the powder form of the given specimens are useful to distinguish the samples even in a mixture form..$^{26,27}$ 


\section{CONCLUSION}

The given samples have been tested as per standard testing protocol. The tuber powder microscopical characters were examined and reported. The extract was tested positive for carbohydrate, coumarins, flavonoids, steroid, tannin, and terpenoid. HPTLC photo documentation, $\mathrm{R}_{\mathrm{f}}$ values and densitometric scan at $254 \mathrm{~nm}, 366 \mathrm{~nm}$ and after derivatisation has been developed and reported.

\section{ACKNOWLEDGEMENT}

The first author is grateful to KSHEMA, NITTE University Deralakatte for the opportunity and Dr. K.V. Chidananada, President, AOLE \& Medical Director KVG Medical college, Sullia for support.

\section{CONFLICT OF INTEREST}

No conflict of interest are declared.

\section{ABBREVIATIONS USED}

A. grossus: Actinoscirpus grossus (L.f.) Goetgh. \& D.A.Simpson; HPTLC: High performance thin layer chromatography.

\section{REFERENCES}

1. Nisteshwar K. Textbook of Dravyaguna. Varanasi, India:Chaukhamba Surbharati Prakashan. 2007;581.

2. Sharma P, Sharma GP. Oshadhi varga. Kaiyadeva nigantu. Delhi, India: Chaukhamba publication; 2006. p.644-5.

3. Kirtikar KR, Basu BD, Blatter E, Caius J F, Mhaskar KS. Indian Medicinal plants, Vol Dehra Dun, India: International Book Distributors. 2007;2644-5.

4. Nadkarni AK, Chopra RN. Indian Materia Medica, Vol-1.Bombay, India:Bombay Popular Prakashan. 1996;1117

5. Kostemans AJ, Wirjahardja, Dekker RJ. The weeds: Description, Ecology and Control. Soerjani M, Kostermans AJ, Tjitrosoepomo. Weeds of rice in Indonesia. Jakarta: Balai Pustaka. 1987;24-565

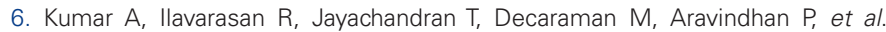
Phytochemicals investigation on a tropical plant, Syzygium cumini from Kattuppalayam, Erode district, Tamil Nadu, South India. Pakistan Journal of Nutrition. 2009;8(1):83-5.

7. Jaradat N, Hussen F, Al Ali A. Preliminary Phytochemical Screening, Quantitative Estimation of Total Flavonoids, Total Phenols and Antioxidant Activity of Ephedra alata Decne. J Mater Environ Sci. 2015;6(6):1771-8.

8. Chothani DL, Patel NM. Preliminary phytochemical screening, pharmacognostic and physicochemical evalution of leaf of Gmelina arborea. Asian Pacific Journal of Tropical Biomedicine. 2012 J;2(3):S1333-7.
9. Remya A, Brindha S, Divya KG, Sunil Kumar KN, Sathiya Rajeswaran P. Atlas of Macro-microscopy of Savuripazham of Siddha - Fruit of Trichosanthes tricuspidata Lour. J Ayu Med Sci. 2017;2(1):153-7. DOI: 10.5530/jams.2017.2.3.

10. Laxmi Bidari, Suma VM, Suchitra P, Sunil Kumar KN. Pharmacognosy, Nutritional Value and Antioxidant Activity of Aglaia elaeagnoidea (A.Juss.) Benth. J Ayu Med Sci 2017;2(1):104-11. DOI: 10.5530/jams.2017.2.4

11. KN Sunil Kumar, Priyadarshini, Pushpendra, BS Holla, B Ravishankar, B Yashovarma. HPTLC as a sensitive method to assess shelf life of multi-herb formulations - a study on Hutabhugadi curna. AYU. 2015;36(3):303-10.

12. Deepa Y, Mohd SR, Sadhana S, Nalini S, Sunil Kumar KN, Sangeeta S. Macromicroscopic evaluation, physicochemical analysis and HPTLC fingerprinting of Curculigo orchioides Gaertn. rhizome. Phcog J. 2016;8(5):430-4.

13. Juliet EC, Mallya SV, KN Sunil Kumar. Authentication and Proximate Analysis of Madhuka indica Gmell. - A Wild Edible Flowers Used for Traditional Fermentation of Ayurvedic Biomedicines. J Ayu Med Sci. 2016;1(1):12-18. DOI: 10.5530/ jams.2016.1.7.

14. Suchitra P, Puneeth, Priyadarshini R, Sunil Kumar KN, Ravishankar B. Comparative Phytochemical and Antioxidant Properties of Costus pictus and C. speciosus. J Ayu Med Sci. 2017; 2(1):121-8. DOI: 10.5530/jams.2017.2.2.

15. KN Sunil Kumar. Macro-and microscopic examination of leaves of Cinnamomum malabatrum (Burm. f.) Blume sold as Tamalapatra. AYU. 2013:34(2);193-9.

16. Deepa $Y$, Mohd SR, Chhavi U, Sadhana S, Nalini S, Sunil KKN, Sangeeta S. Botanical and Chemical Fingerprinting of Medicinal Roots of Justicia gendarussa Burm f. Phcog Res. 2017:9(2);208-14.

17. Yadav D, Reshi MS, Shrivastava S, Srivastava N, Narayana SK et al. MacroMicroscopic evaluation, Physicochemical analysis and HPTLC Finger printing of Curculigo orchioides Gaertn. Rhizome. Pharmacognosy Journal. 2016;8(5).

18. Kumar KS, Ravishankar B, Yashovarma B, Rajakrishnan R, Thomas J. Development of quality standards of medicinal mistletoe-Helicanthes elastica (Desr.) Danser employing Pharmacopoeial procedures. Saudi Journal of Biologica Sciences. 2016;23(6):674-86.

19. Sunil KKN, Sangeetha B, Suchitra P, Ravishankar B, Yashoverma B. Pharmacognosy and quality characterization of fruits of Ingudi-Balanites aegyptica'. IJNPR. 2016:7(1):40-50

20. Patil PS, Shettigar R. An advancement of analytical techniques in herbal research. J Adv Sci Res. 2010;1(1):8-14.

21. Liang $Y Z$, Xie P, Chan K. Quality control of herbal medicines. J Chromatogr $B$ Analyt Technol Biomed Life Sci. 2004;12(5):53-70.

22. Sharma $V$, Pracheta. Microscopic studies and preliminary pharmacognostical evaluation of Euphorbia nerifolia L. Leaves. Ind J of Nat Prod and Res. 2013; 4(4):348-57.

23. Wallis TE. Text book of Pharmacognosy. Delhi: CBS publishers and distributers 1985. p.572.

24. Brain KR, Turner T. The practical evaluation of Phytopharmaceuticals. Bristol: Wright-Scientechnica; 1975.p.10-2.

25. Harborne JB. Phytochemical methods. London: Chapman \& Hall; 1998.p.60-6.

26. Stahl I. Thin layer chromatography. A Laboratory Hand Book (student edition). Berlin: Springer-Verlag; 1969;52-86,127-8.

27. Sethi PD. High Performance Thin Layer Chromatography. New Delhi: CBS Publishers and Distributors; 1996;1-56.
GRAPHICAL ABSTRACT

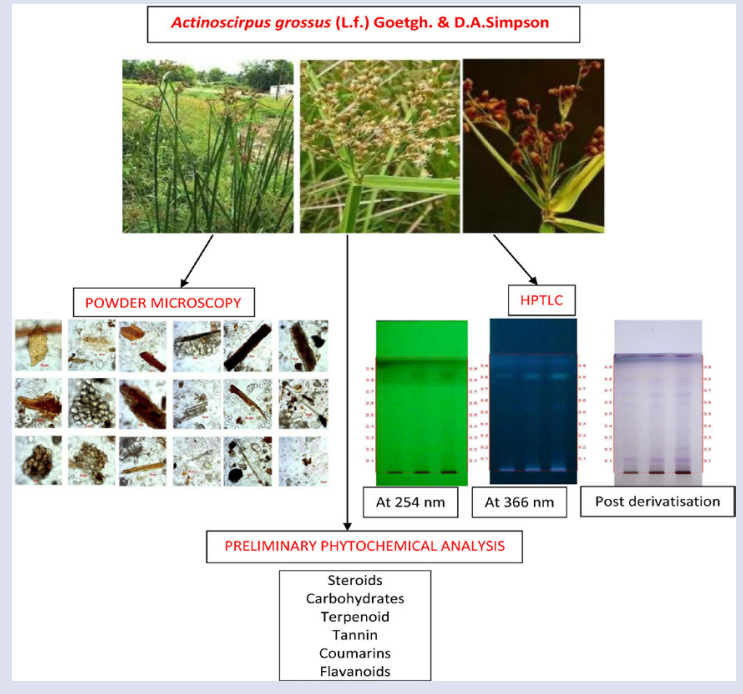

\section{HIGHLIGHTS OF PAPER}

- Powder of tuber of Actinoscirpus grossus (L.f.) Goetgh.\&D.A.Simpson standardized by microscopy

- Ethanol extract of tuber of Actinoscirpus grossus (L.f.) Goetgh.\&D.A.Simpson subjected for preliminary phytochemical examination

- Ethanol extract of tuber of Actinoscirpus grossus (L.f.) Goetgh.\&D.A.Simpson fingerprinted by HPTLC

- Quality standards for tuber powder of Actinoscirpus grossus (L.f.)Goetgh.\&D.A.Simpson proposed for routine testing and analysis of authenticity of the raw drug. 


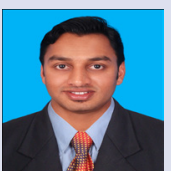

\section{AUTHOR PROFILE}

Mr. Savin CG: MSc Pharmacology is working as Tutor in Department of Pharmacology, KVG Medical College \& Hospital, Sullia, D.K, Karnataka. He has egistered for PhD under KSHEMA, NITTE University Deralakatte, Mangalore, Karnataka. His area of research interest are Hepatoprotective activity and Burn wound healing activity.

Dr. Rajendra Holla MBBS, MD Pharmacology is presently working as Head of Department in Pharmacology in KSHEMA, NITTE University. He has published many papers in National \& International Journals. His areas of research interest are Hepatoprotective activity and antidiabetic activity.

Dr. Shivaraja Shankar M.Sc., Ph.D. Biochemistry is presently working as Head of Department in Biochemistry in KVG Medical College \&Hospital, Sullia, D.K, Karnataka. He has published a book entitled "Laboratory Manual for Practical Biochemistry" and many papers in National \& International Journals. His area of research interest are Saliva and diagnostic markers, fluoride toxicity etc.

Cite this article : Savin GC, Holla R, Shankara S, Sunil NKK, Mundugaru R. Title-Microscopical Evaluation, Phytochemical Analysis and HPTLC Fingerprinting of Tuber of Actinoscirpus grossus (I.f.) GOETGH. \& D.A.Simpson. Pharmacog J. 2017;9(5):657-62. 